\title{
Sonata rubra, Eudocimus ruber
}

O vôo da guará vermelha. REZENDE, Maria Valéria.

Rio de Janeiro: Objetiva, 2005. 184 p.

Eudocimus ruber é o nome da ave que intitula o livro sobre o qual me disponho a gastar pena. Tão rapidamente quanto me dispus a esclarecer o título desta resenha, algumas impressões foram aparecendo à medida que a leitura de $O$ vôo da guará vermelha avançava. Quem eram, afinal, aquelas duas personagens de quem já sabíamos tudo o que estruturalmente se devia saber - culpa da contracapa -, cuja força está justamente naquilo que as une e, extrafisiologicamente, as mantém vivas, mas também metaforicamente as mata a cada dia? É de letras que se nutrem esses dois instrumentos da sonata; de uma homogênea massa feita do real e do ficcional. Vida e literatura em um casamento a la Blake, um matrimônio entre céu e inferno.

Pouco importa à leitura que pretendo relatar, mais que desenvolver, problematizar definições de sonata. Sirvo-me, basicamente, de um modelo conhecido: um instrumento harmônico, outro melódico. Um piano e um trompete, por exemplo. Interessa, sim, o dialogismo desse encontro. Importa, de fato, a maneira pela qual as teclas de Irene ressoam; inicialmente desafinadas, acordes dissonantes que clamam por outros acordes, mas que são respondidos pelo subir e descer das válvulas, pelo grosso dos lábios na embocadura, pelo sopro cortante e pela sonoridade nostálgica do homem dos muitos nãonomes - pequeno, Nem-Ninguém, Curumim, Caroço, Doutor. Ela, piano aos olhos dele. O porte, a beleza, a complexidade constitutiva, a enigmática alternância do preto e branco; e um poder ao qual ele visa, a grafia. $O$ preto da tinta no branco do papel, naturais e bemóis, as linhas sendo preenchidas como a pauta, as mãos dela como as de um maestro. O desejo de se ir a outros mundos, os mesmos de onde as histórias de Rosálio haviam sido trazidas. Mundos de beleza e fome, de feiura e fartura, de contos de fadas; de fados. Lugares "com gosto de vida inteira, talvez curta, porém plena" (p. 147). O passeio na feira, o vestido bonina, o braço dele, ela guiando. E uma velha e um menino, seu, que até então movia sua vivência, antes sobre, agora super. Curumim-trompete é mais que parte do duo sonoro, é quem afina esse instrumento, que o seu pouco carece disso.

Sherazade, embalada em cada movimento da peça, despe-se do gênero: é fenda na boca de Irene, é falo na de Rosálio. Entretanto, até o falo se feminiliza, vira fala, cíclica, dialógica, alternada; harmonia e melodia entrecorta-das pela narração e sustentadas pela escuta um do outro, necessidade evidente das duas personagens. Nesse jogo de discurso e audição, o blefe é peçachave: mentira autorizada, verdade possível que permanece em suspensão até a definição da jogada, no fim do próximo dia. E volta a música. Mil e uma teclas, noite após noite, uma a cada uma; e o sibilo que as acompanha. 
É preciso definir o último movimento. Esperava-se que nele alguns dos temas iniciais fossem retomados, em tonalidades já sentidas, na dominante, talvez. Instrumento pesado, no entanto, o piano. Pesado e doente. Por trás de sua imponência - exacerbada pela inocência de Rosálio , um corpo frágil como se fosse de taipa, de barro, do feitio de uma escola abandonada, bela lembrança da efemeridade dos sonhos iletrados de outrora. E assim débil, sucumbe. Entrega-se a seu último voo, perde a cauda, de encarnado tinge todas as suas teclas. E Rosálio, de improviso, tocando notas que só pode conhecer quando tocar, "soltando [...] palavras" que só pode "conhecer quando disser" (p. 181), transfigura a forma original desse concerto: de allegro a andante, sob um azul sem fim, começa então a compor um bebop para um piano que jaz(z).

Sandro Brincher Universidade Federal de Santa Catarina 